\title{
A Discussion on Autonomous Teachers and How to Get Them Reach Their Utmost Capacity in SLA Classroom
}

\author{
Afsaneh Ghanizadeh ${ }^{1}$, Mohammad Ghazanfari ${ }^{2}$, Mohsen Fatehi ${ }^{1, *}$ \\ ${ }^{1}$ Imam Reza International University, English Department, Mashhad, Iran \\ ${ }^{2}$ Ferdowsi University of Mashhad, Mashhad, Iran \\ *E-mail address: Fatehi4156@gmail.com
}

Keywords: Autonomous teachers; features; meanings; full capacity; second language acquisition

\section{ABSTRACT}

It is of paramount importance for a teacher to do his best and make sve studen are becoming quite a learner, this paper tries to analyze autonomous teacher mea gs, hres, le fner autonomy and how to accelerate the second language acquisition. And $j$ alsonendea some light on developing language teachers' potentials, underst ing all ng their endowments and sharing them among colleagues. It is discussed tha cop ve dev coment can be achieved through collaborative learning and peer observation doctrinat an observing are also needed to fortify professional growth.

\section{INTRODUCTION}

With the increasing prominence of learner autor ny in secor $\mathrm{d}$ language acquisition (SLA), teacher autonomy as a new concept in understanding lea autong ny has been paid more attention to. The discussion of teacher autonomy has alr ${ }^{1}$ becomo y o emerging concern. The analysis of teacher autonomy will be of great help t th derstanding of learner autonomy and the facilitation of SLA.

\section{TEACHER AUTONOMY}

\section{A. Explanation}

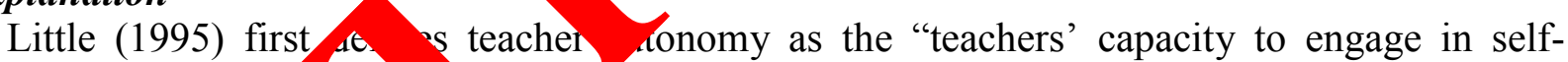
directed teaching." Afto that, olars have been trying to define teacher autonomy from different aspects. Aoki (200\%, orfers an ex, it/definition of teacher autonomy, suggesting that this involves "the capacity, fy edom, and/or reponsibility to make choices concerning one's own teaching". According to kiv omith 2000), teacher autonomy refers to "the ability to develop appropriate skills, knowledge à ttitud s for oneself as a teacher, in cooperation with others." Benson (2000) argues "at, ther au my can be seen as "a right to freedom from control (or an ability to exerg this ght) as wedl as actual freedom from control". Nevertheless, these definitions focus on the abil r wam rs, failing to point out the dynamic relationship between the teacher and learners. I abjlity of these learners may influence the teacher's capacity of managing their knowledge, sk $1 \mathrm{~s}$ and even attitudes, and vice versa. Therefore, the author puts forward her point of view on teacher autonomy. It means the capacity of teachers in managing knowledge, skills, and attitudes in the students' acquisition of a language with regard to learners.

\section{B. Features}

Researchers have been analyzing teacher autonomy from different dimensions. McGrath (2000) illustrates the characteristics of teacher autonomy from two dimensions, "as self-directed action or development; as freedom from control by others." When teachers act in a self-directed manner, they are not guaranteed to learn from the experience. Because their professional development of autonomy could be considered as one form of professional action, but their action 
and development of autonomy do not necessarily mean the same thing. When teachers make use of their self-direction and actual self-directed behavior.

\section{Teacher Autonomy and Learner Autonomy}

It is of vital importance to understand the dynamic relationship between teacher autonomy and learner autonomy. They are interrelated and interactive. To put it specifically, in order to understand and instruct learners, teachers become involved in various activities, asking questions which are helpful in increasing students' awareness of autonomous learning. Smith (2001: 43-4) explains explicitly their relationship. "Teachers also need to constantly reflect on their own role in the classroom, monitoring the extent to which they constrain or scaffold students' thinking and behavior, so as to engage students in autonomous and effective learning". According trafferent circumstances, teachers' management of autonomy vary respectively. However, Littio 991) points out that learner autonomy does not mean "learning without a teacher home, $\mathrm{b}$ a computer, in a self-access center, etc.), and/or that it does away with the need a teac er". Instead, learner autonomy concerns a capacity (for taking control of carning) th a an be cultivated and explored in a number of ways and situations, especially the ssroon with the help of teacher autonomy. Scholars become more aware of both the ance 9 developing teacher autonomy in structuring or scaffolding reflective learnir and of cop plex, shifting interrelationship between teacher and learner roles in the ady ca of learn autonomy. As a result, teachers are required to get fully prepared for ther nomy besides, as Carey emphasizes, teacher autonomy is wrongly "coupled w 11 uniformity Tachers tend to adopt uniform teaching in order to meet the existing standard f teacher evaluation. Consequently, teacher autonomy has been linked to the same pattern of teachi According y, Tholin (2009) observes that "The focus here is both on teachers" freedom to ro ect their/eaching towards self-directed learning and on how their own experiences as antonomo age learners can give character to the teaching that they themselves carry out." T in order to avoid such uniformity teachers' freedom should be taken into serious considerat n. 'tan felopment is to bring about changes in teachers' instructional practices, students' learn 'g outcomes and teachers' beliefs and attitudes, which requires educational leaders $0 \mathrm{p}_{\mathrm{k}}$ ide and facilitate as much opportunities and training as they can to develop their staff to ful ontential. Actively using every valuable chance of formal and informal training progran the st sup overy staff to be their best selves.

\subsection{KNOWLEDGE $O$ Th THERS, $>$ RENGTHS}

In the same wa thut indi learners have different ways of learning at their best, teachers each have their oy $n$, individual $w$ of being the best teacher that they can be. Each individual is unique and has tincti talent. Therefore, the first step in developing the potential in others is to understand and $a_{\text {a }}$ ciate $t$ se talents. Then cultivate these talents by providing inspiration, support ar portu. as to teachers as they work toward refining and sharing their strengths. A very ir borta and ef ave way of helping the staff recognize their own strengths is providing opport $v f$ individual to reflect or self-evaluate. This can take many forms, such as formal evaluation rms, professional portfolios, peer observation, interest group. A good evaluation form, which inclu most of the important ingredients for effective teaching and professional development, will be a guide for the staff to their future grow and full play of their potential.

\subsection{COLLABORATIVE LEARNING}

Collaborative learning is designed to build colleagueship among teachers to prevent isolation from one another so that they can share common problems and collective solutions. Teachers can develop collaboration relationship through interchanging with one another within the informal system of the school and college. Collaboration naturally complements autonomy. Freedom to direct one's own learning is a vital aspect of collaboration. Collegial groups must be flexible in their composition and purpose. They must form and disintegrate based on the needs of individual teachers. And it is teachers who must decide on the specifics of their collaboration. Participation in 
cooperative collegial groups can expand teachers' levels of expertise by supplying a source of intellectual provocation and new ideas. A collaborative group can furnish the emotional support and encouragement teachers need to cope with the risk that is inherently involved in learning to teach well. Colleagues can demonstrate to one another that they value attempts at growth and reassure group members that the effort and pain are worth it.

\section{A. Cooperative Development}

It offers a practical way of working towards the widely accepted goal of autonomous development. Attentive listening is the way to effective communication, to better solutions and to facilitating staff grow as well. Teachers can encourage each other's professional development by learning to talk and listen to each other in a way that allows to take the whole idea of (along with the exchange of comments, opinions, suggestions and advice) out the tion altogether for an agreed period of time. This allows the person who needs sound board the tra space in which to work on their own development in a way that facilitates the oro of their swn ideas, while also encouraging an increase in collegial feeling among the lan arage teach iny sved.

\section{B. Fellow Observation}

It is the case that even the finest teachers can still learn. Fel ow observ of teaching is of growing importance in higher education both for purposes of a se ent and a copment. Fellow observation gives teachers an opportunity to learn from each her in a non-threatening environment. Observing other teachers' teaching can giy mon new id for their own teaching and illustrate techniques they might never have thou at of. Being observed by others from the committee and from the department also can give ideas bout how th class looks from the student's perspective, and about things we might try in order to in ase the ef ectiveness of teaching.

\subsection{SUPERVISION}

Teachers need training, follow-up and te hni ar stance provided by respected persons. They also need ongoing coaching and feedback oy credible persons. Such training activities as seminars, workshops and conferen es o the cam us or off the campus are the most popular, in which diagnosing and prescribi ivin informan and demonstrating, discussing application, practicing and giving feedb? stimulate and reinforce tea ers' profes nal growth through informal but focused communication and supervision.

\section{A. Inducing Ince aves}

Some poc e fac or data on/off the campus can be used to introduce a new idea or concept to raise teachers rest. In rming teachers of all kinds of professional opportunities, such as situations rses, h res oooks, language teachers and all manner of other things that will help them $g$ ow, $t_{1}$ bugh en $A$ and announcements - providing bit of information about a program or encour. $\mathrm{g}$. professional interests - are ways in which, through relatively small actions, can exert 'emental influence on teachers' development.

\section{B. Motivating}

Staff members will be pleased if their professional growth interest is appreciated. Disseminating professional and curriculum materials - duplicated and distributed articles, hands out curriculum materials, lend books to individual teachers and set up displays for their faculties in central locations - personal one-to-one follow-up seems to have a positive influence on teachers' responses to the activities. Conversational inquiries soliciting teachers' opinions about a display or an article may have increased the impact of the disseminated materials by promoting teachers exposure to them. If the teachers have not read them, the summary of some ideas or questions can be provided to them. Some teachers, apparently motivated by the questions, will read the articles and then express their opinions. 


\section{Appraisal}

One of the key points in staff development is to convey support for the staffs in general attention as well as in informal conversation, which can guide and encourage language teachers to stretch them from their current reality towards their potential. Teachers in turn willing to experiment with new or innovative tech because they feel their dean is supportive and would not penalize them for experiments that failed. The attitude of the dean is crucial factor in the willingness of the staff to pursue new ideas and programs - opportunities for both personal and professional growth. We are never too old to hear praise. Working very hard to find something positive as often as possible will be positive reinforcement which is a valuable tool for a change not only in the praised, but also in the others. What's more, it is also a powerful tool that can be good for the praiser, who will find it easier to help language teachers reach their full potentials

\section{Perceptivity}

One way to help individual staff members to grow is to understand, apprer ate a utilize heir strengths. If we can recognize teachers' positive efforts with specific recog ition we o helr them see specific areas of value. For example, acknowledging that a teacher $d^{\prime}$ an ef tive jo of using questioning skills during a class period can help reinforce this teachip sty the sa time, this kind of authentic praise will have impact on other teachers or car arouse th inter -st. Individual teacher's achievements can be recognized by publicizing teach s cesses by aking about them to parents, other teachers and other higher leaders. Also encou gge to hers to seek info/assistance from successful colleagues, which provide opportunities $\mathrm{n}$ on $y$ for ins onal improvement, but also for increased self-esteem for the teachers whose $\mathrm{sp}$ cial work was being recognized.

\section{CONCLUSION}

In short, it is of great necessity to inve inte inmer autonomy if teachers intend to engage successfully in advocating learner auto Ony cecond language acquisition. As a result, this brief analysis of the definitions and chara te istics of teacher autonomy is very helpful to understand learner autonomy and to facil ate SLA by consciously developing teachers' capacity and freedom in knowled skil and atti ces. Most of us find ourselves in a position to help others achieve more of then te realize. Sure, as leaders, one must be well qualified to help their staff $r$ ach then tential. I believe it is part of the purpose to serve others in this way - to encourage a oport lang teachers we care about in becoming their best selves.

\section{References}

[1] Little, D 5) Thening as dialogue: The dependence of learner autonomy on teacher autonomy. System 2. 175- 2 .

[2] Aol , N. 2000) D.cts of teacher autonomy: Capacity, freedom and responsibility. Paper prese. at 2.00 Hong Kong University of Science and Technology Language Centre Conference.

[3] Smith, C. (2000) Starting with ourselves: Teacher-learner autonomy in language learning. In B. Sinclair, McGrath and T. Lamb (eds.) Learner autonomy, teacher autonomy: Future directions. London: Longman. 89-99.

[4] Benson, P. (2001) Teaching and researching autonomy. Language Learning. London: Longman.

[5] McGrath, I. (2000) Teacher autonomy. In B. Sinclair, I. McGrath and T. Lamb (eds.) Learner autonomy, teacher autonomy: Future directions. London: Longman. 100-110

[6] Smith, R.C., with A. Barfield (2001) Interconnections: Learner autonomy, teacher autonomy (in 2 parts). Language Learning $7 \& 8 / 1$. 5-6.

[7] Smith, R.C. (2001) Learner and teacher development: Connections and constraints. The Language Teacher 25/6: 43-4. 
[8] Little, D. (1991) Learner autonomy: Definitions, issues and problems. Dublin: Authentic.

[9] Voller, P. (1997) Does the teacher have a role in autonomous language learning? In P. Benson and P. Voller (eds.) Autonomy and independence in language learning. London: Longman. 98-113.

[10] Carey, Kevin. (2008) the Teacher Autonomy Paradox. The American Prospect. September 17.

[11] Tholin, J. (2009) Learner and Teacher Autonomy: Concepts, Realities, and Responses. ELT J. 63: $179-181$

[12] Edge, J. (1993). Cooperative development: Professional self-development through cooperation with colleagues (Teacher to Teacher). Harlow: Longman.

[13] Edge, J. (2002). Continuing cooperative development: A discourse framework fo viduals as colleagues. Ann Arbor: The University of Michigan Press.

[14] Stiggins, R. J. \& D. Duke (1988). The case for commitment to teacher gro Researc on teacher evaluation. NY: SUNY Press.

[15] Brandt, R. S. (Ed.) (1989). Coaching and staff development: leadership. Alexandria, VA: ASCD.

[16] Whitaker, T., B. Whitaker \& D. Lumpa (2000). Motiv g \& ins no teachers: The educational leader's guide for building staff morale. Larchmon NY. on Edu ation.

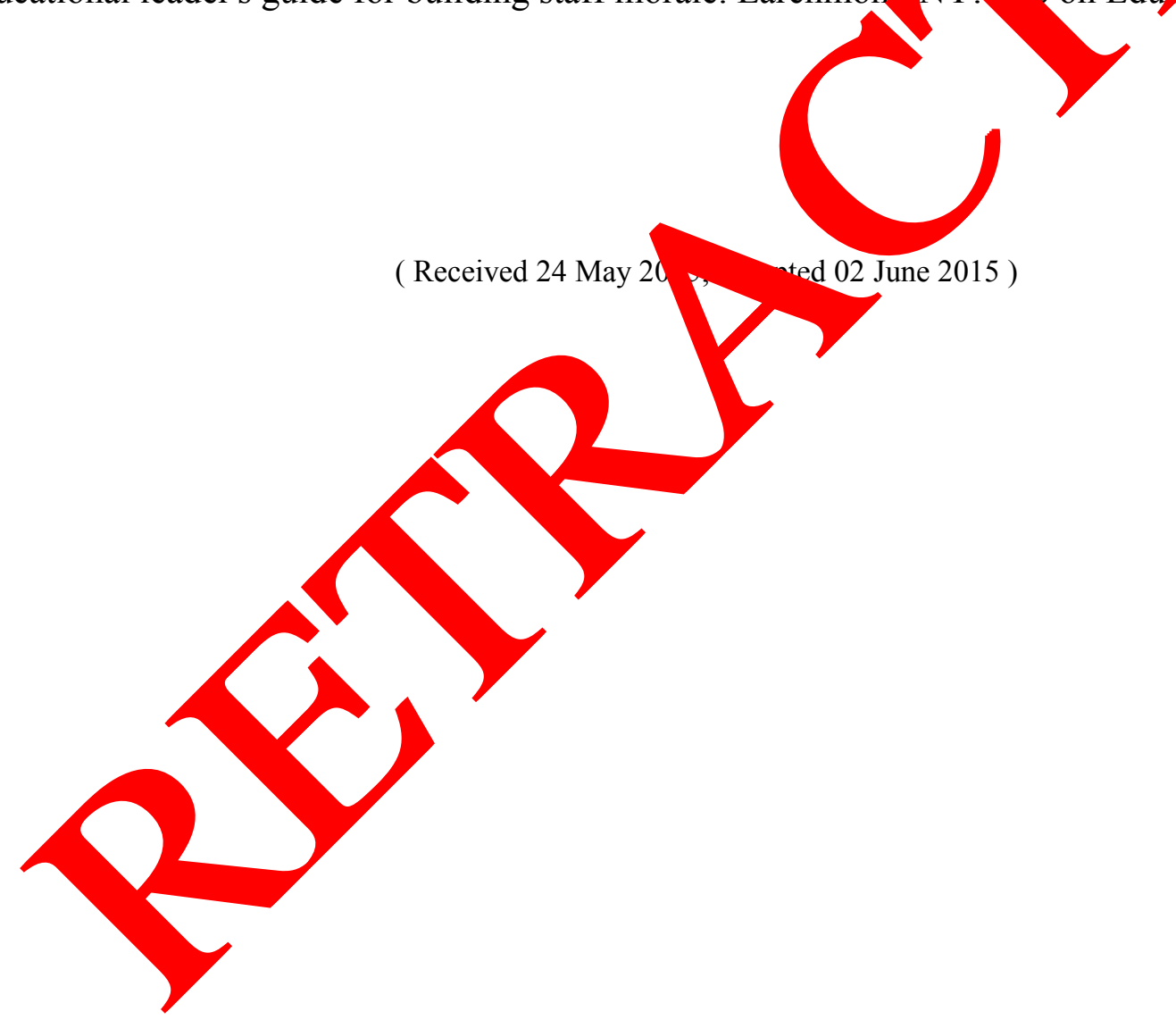

